\title{
PADEPOKAN SENI DAN BUDAYA MELAYU KALIMANTAN BARAT
}

\author{
Muhammad Ikhsan', Hamdil Khaliesh ${ }^{2}$, Irwin ${ }^{3}$ \\ ${ }^{1}$ Mahasiswa, Program Studi Arsitektur, Fakultas Teknik, Universitas Tanjungpura \\ icanlittle@student.untan.ac.id \\ ${ }^{2}$ Program Studi Arsitektur, Fakultas Teknik, Universitas Tanjungpura \\ ${ }^{3}$ Program Studi Arsitektur, Fakultas Teknik, Universitas Tanjungpura
}

Naskah diajukan pada: 16 Februari 2021

Naskah revisi akhir diterima pada: 17 Februari 2021

\begin{abstract}
Abstrak
Kota Pontianak memiliki potensi untuk pelatihan dan pengembangan kesenian budaya Melayu. Kesenian yang ada di Kalimantan Barat pada umumnya meliputi seni tari, seni musik, teater (cerita rakyat) kerajinan tangan. Event-event khusus yang ada di Kalimantan Barat akan menjadi puncak dari pagelaran seni dan budaya tersebut, yaitu melalui festival-festival. Kesenian ini dapat dijadikan andalan untuk menghadapi Masyarakat Ekonomi ASEAN. Proyek Tugas Akhir Padepokan Seni dan Budaya Melayu Kalimantan Barat bertujuan untuk menghasilkan rancangan bangunan khusus seni dan budaya Melayu dengan ruang lingkup pendidikan seni budaya, rekreasi, dan wisata yang dapat menarik minat masyarakat. Batasan perancangan melingkupi seni musik, tari, teater, kriya, dan memasak yang berada dalam wilayah Kalimantan Barat. Metode perancangan Padepokan Seni dan Budaya Melayu Kalimantan Barat dilakukan dalam beberapa tahap yaitu gagasan, pengumpulan data, identifikasi, analisis, sintesis, dan pengembangan rancangan. Konsep yang digunakan dalam perancangan didasarkan pada Standar Sarana dan Prasarana Lembaga Kursus dan Pelatihan Tahun 2017. Analisis perancangan menghasilkan tiga fungsi, yaitu fungsi primer (pendidikan), sekunder (administrasi, pameran, pertunjukkan), dan tersier (pemeliharaan). Hasilnya ketiga fungsi tersebut dikombinasikan dalam satu menjadi sembilan bangunan utama dengan pola organisasi ruang terpusat, sirkulasi melingkar, fasad, dan bentuk berkarakteristik Melayu.
\end{abstract}

Kata-kata Kunci: Padepokan, seni dan budaya, Melayu, vernakular

\begin{abstract}
Pontianak City has the potential for training and development of Malay cultural arts. The arts in West Kalimantan generally include dance, music, theater (folklore) and handicrafts. Special events in West Kalimantan will be the culmination of these arts and cultural performances, namely through festivals. This art can be used as a mainstay to face the ASEAN Economic Community. The final project of the Malay Art and Culture Hermitage of West Kalimantan aims to produce a special building design for Malay art and culture with the scope of cultural arts education, recreation, and tourism that can attract public interest. Design boundaries include the arts of music, dance, theater, crafts and cooking in West Kalimantan. The design method of the Malay Art and Culture Hermitage of West Kalimantan was carried out in several stages, namely ideas, data collection, identification, analysis, synthesis, and design development. The concept used in the design is based on the Facilities and Infrastructure Course and Training Institute Standards in 2017. Design analysis produces three functions, namely primary (education), secondary (administration, exhibition, performance) and tertiary (maintenance) functions. The result is that these three functions are combined in one into nine main buildings with a centralized organizational pattern of space, circular circulation, facades, and forms with Malay characteristics.
\end{abstract}

Keywords: Padepokan, arts and culture, Malay, vernacular

\section{Pendahuluan}

Sejak Tahun 2015, mulai diberlakukan MEA yang memungkinkan satu negara dengan mudah mendapatkan informasi mengenai perkembangan kondisi negara lain. Salah satu yang menjadi 
perhatian yakni perkembangan kesenian dan budaya sebagai identitas suatu negara. Indonesia merupakan salah satu negara yang terkenal dengan keanekaragaman seni dan budayanya. Indonesia memiliki peluang untuk memperkenalkan identitasnya pada dunia Internasional untuk memajukan seni dan kebudayaan setempat. Untuk memperkuat identitas budaya setempat, diperlukan wadah berupa lembaga pelatihan untuk membentuk sumber daya manusia yang memiliki pengetahuan dan keterampilan seni dan budaya.

Sebagai Ibukota Provinsi Kalimantan Barat, Kota Pontianak memiliki potensi untuk pelatihan dan pengembangan kesenian budaya Melayu. Kota ini berada di tepi Sungai Kapuas yang memiliki kaitan erat dengan jalur transportasi andalan pada masa lampau. Oleh karena itu kota ini lebih banyak ditempati oleh etnis Melayu dengan kebudayaan Melayu dan Islam seperti kebanyakan kotakota di bagian barat Indonesia yang berada di tepian sungai (perairan).

Kesenian yang ada di Kalimantan Barat pada umumnya meliputi seni tari, seni musik, teater (cerita rakyat) kerajinan tangan. Event-event khusus yang ada di Kalimantan Barat akan menjadi puncak dari pagelaran seni dan budaya tersebut, yaitu melalui festival-festival. Kesenian ini dapat dijadikan andalan untuk menghadapi MEA. Fasilitas pengembangan kebudayaan di Kalimantan khususnya di Kota Pontianak sebagian besar berada pada Taman Budaya Kalimantan Barat. Taman Budaya ini menaungi semua kebudayaan yang berada di Kalimantan Barat secara umum.

Selain minimnya fasilitas, pengenalan seni dan budaya Melayu sebagai kekayaan budaya potensial kepada masyarakat belum tercapai sepenuhnya. Pengenalan lebih lanjut bertujuan dalam pelatihan dan pengembangan calon seniman sejak dini serta seniman profesional. Penyediaan fasilitas pelatihan seni dan budaya Melayu dapat menjadi cara untuk memperkenalkan budaya ini kepada masyarakat Kalimantan Barat sebagai fasilitas pendidikan, budaya, dan rekreasi.

Berdasarkan uraian di atas, maka diperlukan sebuah sarana pelestarian seni dan budaya Melayu di Kalimantan Barat. Pengadaan sarana dan prasarana untuk lembaga pelatihan kesenian mengacu pada Standar Sarana Dan Prasarana Lembaga Kursus Dan Pelatihan Direktorat Pembinaan Kursus dan Pelatihan Ditjen Pendidikan Anak Usia Dini Dan Pendidikan Masyarakat Kementerian Pendidikan Dan Kebudayaan 2017 dalam rangka memberikan layanan prima bagi pesera didik kursus dan pelatihan serta menghasilkan lulusan yang berkualias dan memiliki daya saing bagi setiap cabang kesenian yang dimaksud.

\section{Kajian Pustaka}

Menurut Kamus Besar Bahasa Indonesia (2019), padepokan berarti tempat persemedian, tempat pengasingan raja-raja dimasa lalu. Di era sekarang, istilah padepokan lebih sering digunakan oleh kegiatan "Sanggar Seni Tari" dan "Pencak Silat", difungsikan sebagai tempat bertemu, bersilaturahim dan berlatih bersama. Sedangkan dari istilah arsitekturnya padepokan juga mempunyai makna sebagai komplek perumahan (bangunan) dengan areal yang cukup luas yang disediakan sebagai tempat untuk proses belajar dan mengajar keterampilan tertentu.

Menurut Soedarso (1988: 16-17) bahwa kata seni berasal dari bahasa Sansekerta sani yang berarti pemujaan, palayanan, donasi, permintaan atau mata pencaharian dengan hormat dan jujur. Dalam versi yang lain seni disebut cilpa yang berarti berwarna (kata sifat) atau pewarna (kata benda) kemudian berkembang menjadi cilpasastra yang berarti segala macam kekriyaan (hasil keterampilan tangan yang artistik. Dari beberapa arti kata tentang seni disimpulkan bahwa seni adalah benda atau karya seni atau hasil kegiatan yang menghasilkan kesenangan, tetapi berbeda dengan sekedar rasa gembira karena mempunyai unsur transendental atau spiritual. Seni memiliki 5 cabang, yaitu seni rupa, seni teater, seni musik, seni tari dan seni sastra. Masing-masing cabang seni tersebut memiliki pengertian dan fungsi yang berbeda. Dari seiarah asal-usul kata (bahasa) Indonesia pengertian budaya berasal dari bahasa sansekerta yaitu Buddayah yang merupakan bentuk. jamak dari Buddhidaya. Buddhi artinya akal dan Daya artinya kekuatan (Koentjaraningrat, 1974:80), jadi dapat dikatakan budaya adalah kekuatan akal atau hal-hal yang bersangkutan dengan akal. 
Menurut Elhulaimy (1963), Melayu berasal dari kata Mala (yang berarti mula) dan $Y u$ (Negeri) dan kata Melayu dikenal sekitar tahun 644 Masehi. Pengertian orang Melayu dapat dibedakan atas beberapa kategori pertama Melayu Tua (Proto Melayu) dengan Melayu Muda (Deutro Melayu).

Dari definisi di atas dapat disimpulkan bahwa Padepokan Seni Budaya Melayu adalah komplek perumahan (bangunan) dengan areal yang cukup luas yang disediakan sebagai tempat untuk proses belajar dan mengajar pengetahuan dan keterampilan seni dan budaya Melayu untuk menghasilkan suatu karya, hasil pemikiran, ataupun ide yang menjadi ciri khas dari khazanah masyarakat Melayu khususnya daerah Kalimantan Barat.

\section{Metode}

Metode perancangan adalah alat untuk mengetahui sesuatu melalui tahapan-tahapan yang sistematis. Tahapan-tahapan dalam penyusunan proyek tugas akhir ini berdasarkan Jones (1980) adalah tahap gagasan, tahap pengumpulan data, tahap analisis, tahap sintesis, dan tahap rancangan. Tahap gagasan merupakan tahap persiapan untuk merumuskan latar belakang, rumusan masalah, tujuan, sasaran dan manfaat untuk memenuhi pekerjaan secara keseluruhan. Tahap pengumpulan data merupakan tahap mendapatkan data dan informasi mengenai materi dari judul proyek menggunakan tiga metode berupa pengumpulan data observasi lapangan, pengumpulan data dari literatur, pengumpulan data dari studi kasus bangunan-bangunan yang memiliki fungsi bangunan yang sama. Tahap analisis adalah tahap pengolahan data-data dari hasil pengumpulan data untuk menemukan pemecahan dan solusi dari permasalahan-permasalahan melingkupi analisis eksternal, analisis internal, struktur, utilitas, bentuk, dan fisika bangunan. Tahap sintesis merupakan pemikiran terhadap konsep pemecahan masalah dengan medianya yaitu bangunan hasil rancangan. Tahap rancangan merupakan tahap desain atau penerapan sintesis melingkupi tema, komponen fisik alamiah, efektivitas dan kenyamanan ruang serta kesesuaian desain terhadap lingkungan sekitar.

\section{Hasil dan Pembahasan}

Berdasarkan Peraturan Menteri Pendidikan dan Kebudayaan Republik Indonesia Nomor 127 Tahun 2014 Tentang Standar Sarana dan Prasarana Lembaga Kursus dan Pelatihan, beberapa kriteria yang harus sesuai dalam pemilihan lokasi, yaitu tata ruang dan infrastruktur, luas lahan tersedia, topografi dan kondisi lahan, klimatologi dan kelestarian lingkungan. Area terpilih sebagai lokasi perancangan berada di Jl. Khatulistiwa, Kelurahan Batu Layang, Kecamatan Pontianak Utara, Kota Pontianak, Kalimantan Barat. Berdasarkan data survey lokasi, Kelurahan Batu Layang memiliki fungsi-fungsi yang meliputi, fungsi pendidikan, budaya, dan wisata, Kawasan Pemakaman Kesultanan Pontianak, Kawasan Khatulistiwa Park dan Kawasan SMP 15 dan SMKN 2 Pontianak.

Di sisi Utara (depan) site berbatasan dengan area permukiman warga. Sisi Selatan (belakang) site berbatasan dengan Sungai Kapuas. Sisi Timur (kanan) dan Sisi Barat (kiri) site bersebelahan dengan area industri. Menurut Rencana Tata Ruang Wilayah (RTRW) Kota Pontianak (2013) mengenai data peraturan lingkungan Koefisien Dasar Bangunan (KDB) pada area perancangan sebesar 60\%, Koefisien Lantai Bangunan (KLB) sebesar 2,4. Garis Sempadan Bangunan (GSB) sebesar 10 meter. Tautan lingkungan perancangan Padepokan Seni dan Budaya Melayu Kalimantan Barat disajikan pada Gambar 1. 


\section{TAUTAN LINGKUNGAN}

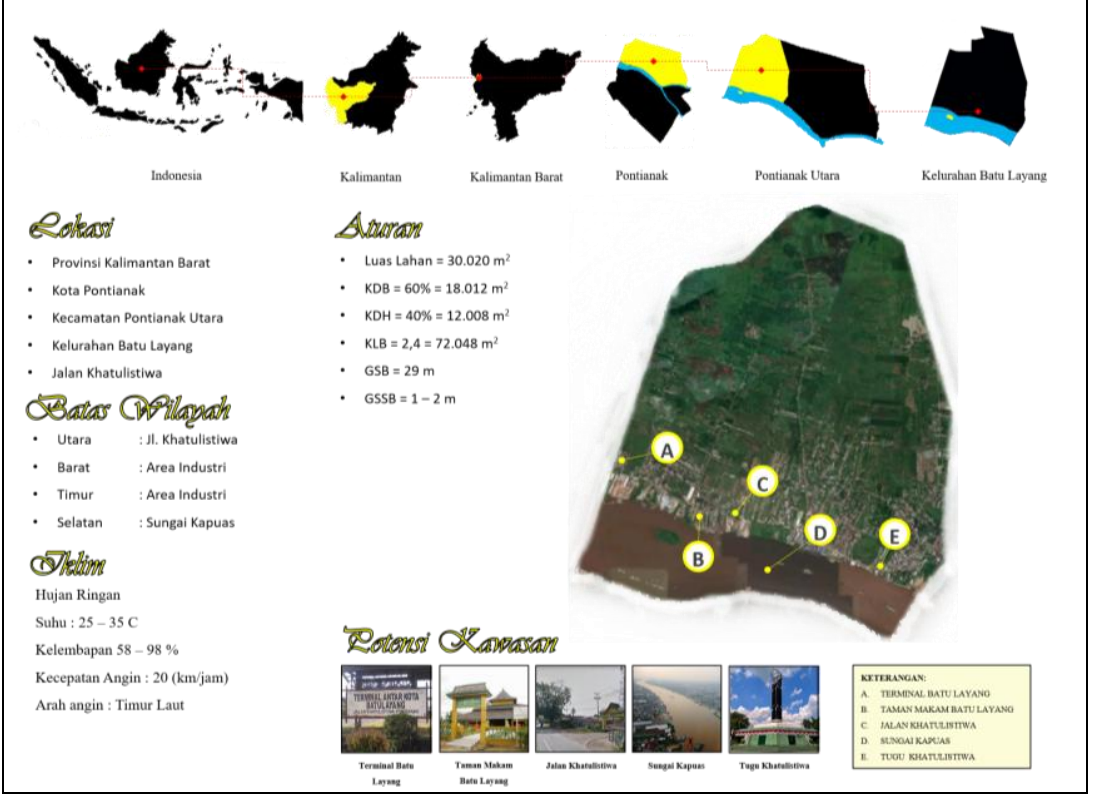

Gambar 1. Tautan Lingkungan Lokasi Perancangan Padepokan Seni dan Budaya Melayu Kalimantan Barat

Sumber: Penulis, 2020

\section{Landasan Konseptual}

Fungsi perancangan terbagi menjadi 3 fungsi, yaitu primer, sekunder dan tersier. Fungsi primer perancangan diperuntukkan sebagai unit pelayanan pendidikan dengan ruang lingkup kegiatan pendidikan seni musik, tari, teater, kriya, dan kuliner. Fungsi sekunder diperuntukkan sebagai fungsi pendukung fungsi primer, seperti fungsi administrasi, pameran, dan pertunjukkan. Fungsi tersier bertanggung jawab atas kelancaran operasional bangunan, pelaksanaan pengoperasian dan perawatan. Penjabaran analisis fungsi perancangan disajikan pada Gambar 2.

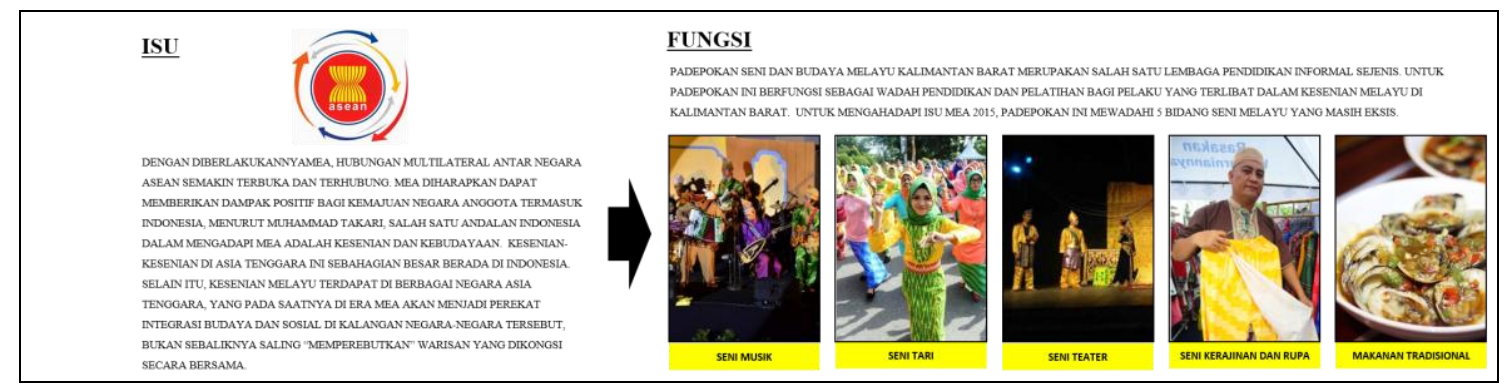

Gambar 2. Fungsi Padepokan Seni dan Budaya Melayu Kalimantan Barat

Sumber: Penulis, 2020

\section{Hasil Perancangan}

Analisis pelaku didasarkan pada masing-masing fungsi yang ada di Padepokan Seni dan Budaya Melayu Kalimantan Barat. Fungsi pendidikan membagi jenis pelaku menjadi murid dan seniman. Fungsi administrasi membagi jenis pelaku menjadi pengelola dan pengelola penunjang. Fungsi pameran dan pertunjukkan membagi jenis pelaku menjadi pengunjung dan penyewa. Fungsi terakhir yaitu fungsi pemeliharaan yang membagi jenis pelaku menjadi petugas servis.

Analisis eksternal terbagi menjadi zonasi, perletakan, orientasi, sirkulasi dan vegetasi perancangan Padepokan Seni dan Budaya Melayu Kalimantan Barat. Analisis zonasi dapat dilihat pada Gambar 5. Analisis Zonasi mengacu pada data kebisingan, sirkulasi, dan pandangan ke dalam 
maupun keluar site. Hasil analisis berupa perletakan zonasi publik sebagai pusat interaksi budaya didalam site. Zona semi publik dan semi privat menjadi zona transisi yang tehubung dengan zona privat disekeliling site. Zona servis menjadi batas akses dengan lingkungan diluar site. Analisis zonasi mempertimbangkan efektivitas waktu pencapaian, menghindari kebisingan, dan memicu interkasi sosial pelaku.

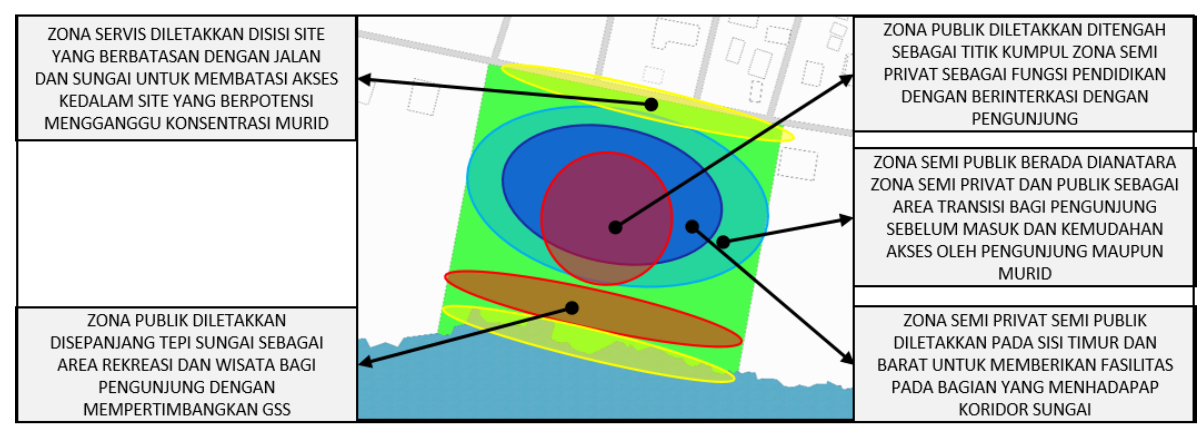

Gambar 3. Analisis Eksternal Zonasi Padepokan Seni dan Budaya Melayu Kalimantan Barat Sumber: Penulis, 2020

Analisis perletakan dapat dilihat pada Gambar 4. Perletakan bangunan tidak berada di luar dari garis sempadan bangunan dan garis sempadan samping bangunan. Area yang berada di luar dari garis sempadan dan sempadan samping bangunan tersebut berfungsi sebagai taman, pedestrian, jalan, dan ruang terbuka. Fokus awal peletakan massa pada bagian depan kawasan yaitu gedung utama, masjid, dan bangunan pengelola. Gedung pengelola, masjid dan bangunan pameran/pertunjukkan berada di area depan kawasan agar memudahkan pengunjung atau tamu dalam pengurusan administrasi, beribadah dan melaksanakan event tertentu.

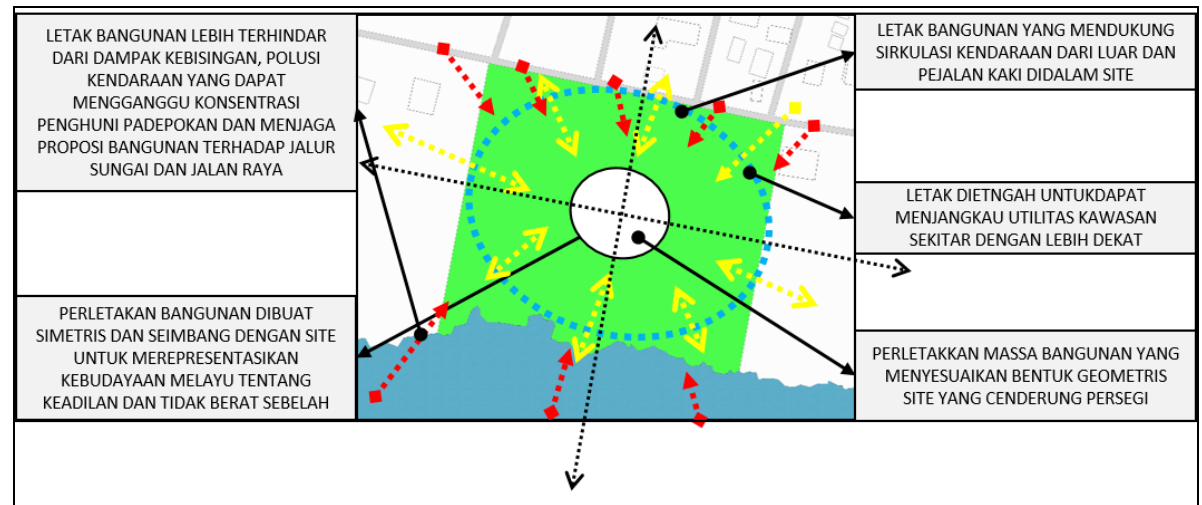

Gambar 4. Analisis Eksternal Perletakan Padepokan Seni dan Budaya Melayu Kalimantan Barat

Sumber: Penulis, 2020

Analisis orientasi dapat dilihat pada Gambar 5. Orientasi bangunan dikawasan mengacu pada bentuk site, keistimewaan alami, keistimewaan buatan, dan view kedalam dan keluar site. Bangunan depan site di orientasikan kearah Jl. Khatulistiwa untuk mempermudah identifikasi bangunan oleh pengguna jalan. Pada area belakang site, bangunan diorientasikan kearah sungai untuk mencerminkan kondisi permukiman Melayu pada masa lampau. Selain itu, bangunan yang berada ditengah site di orientasikan kedalam sebagai ruang interaksi bangunan dan pengguna yang berkumpul ditengah. 


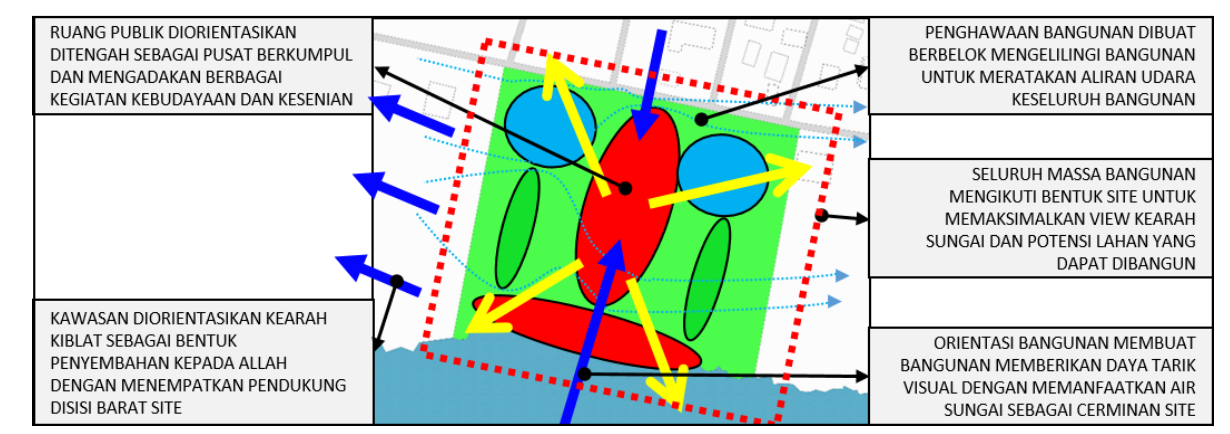

Gambar 5. Analisis Eksternal Orientasi Padepokan Seni dan Budaya Melayu Kalimantan Barat Sumber: Penulis, 2020

Analisis sirkulasi dapat dilihat pada Gambar 6. Hasil analisis untuk alur masuk dan keluar site melalui Jl. Khatulistiwa dengan pertimbangan akses utama memiliki sirkulasi 2 arah, akses untuk kendaraan motor roda dua dan roda empat dengan tingkat kemacetan yang rendah. Berdasarkan pertimbangan pola pencapaian, pengunjung akan dipermudah jalurnya bila menggunakan pola pencapaian melingkar. Zona parkir diletakkan tidak menutupi bangunan dan berdekatan dengan Jl. Khatulistiwa. Zona parkir dibagi menjadi 3 yaitu zona parkir murid dan zona parkir pengelola/servis, dan zona parkir pengunjung.

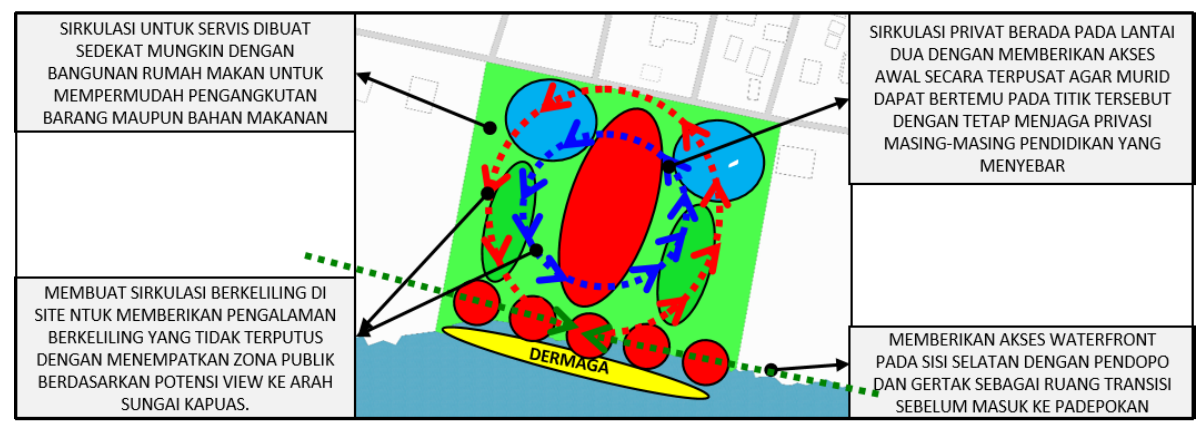

Gambar 6. Analisis Eksternal Sirkulasi Padepokan Seni dan Budaya Melayu Kalimantan Barat Sumber: Penulis, 2020

Analisis vegetasi dapat dilihat pada Gambar 7. Pada site perancangan terdapat beberapa tanaman yang menghalangi pemandangan seperti rumput ilalang dan tanaman perdu. Tanaman ini dipangkas untuk ditata ulang. Perletakan tanaman pada area depan menggunakan pohon trembesi sebagai peneduh jalur pedestrian dan buffer kebisingan dari Jl. Khatulistiwa. Untuk area tengah site menggunakan pohon palem sebagai pengarah jalur pejalan kaki didalam site. Untuk area tepi sungai menggunakan pohon ketapang sebagai penahan abrasi pada tanah ditepi sungai.

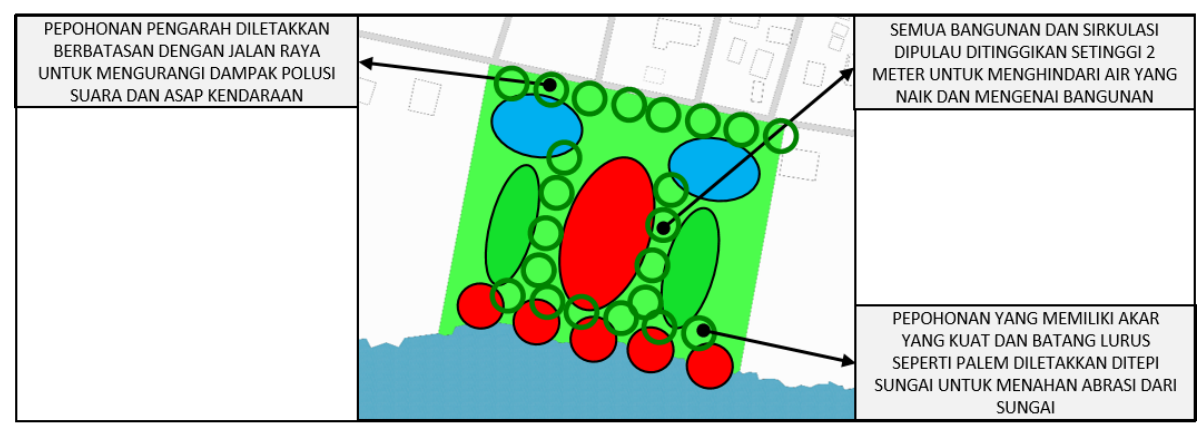

Gambar 7. Analisis Eksternal Vegetasi Padepokan Seni dan Budaya Melayu Kalimantan Barat Sumber: Penulis, 2020 
Analisis bentuk berdasarkan pada bentuk area utama, yaitu area belajar-mengajar, pameran, dan pertunjukkan. Fungsi lainnya disusun mengelilingi plaza dan panggung outdoor mengikuti ketentuan zonasi komunal. Dari analisis gubahan bentuk, konsep gubahan bentuk padepokan dapat dikembangkan menjadi 4 proses yang disajikan pada Gambar 8. Pada proses pertama, dilakukan identiikasi bentuk lahan yang memiliki luas 3,02 Ha dan dapat diakses dari Jl. Khatulisiwa dan Sungai Kapuas. Pada proses kedua, bangunan dibentuk persegi dengan memaksimalkan lahan yang tersedia dan mengidentifikasi arah timur dan barat. Selanjutnya pada proses ketiga, bangunan dibagi menjadi 9 berdasarkan zona dan fungsi. Pada proses terakhir, orientasi muka bangunan ditonjolkan dengan massa yang ditambah dan diperkuat dengan karakter bentuk Melayu yang simetris dan atap bertingkat limas.

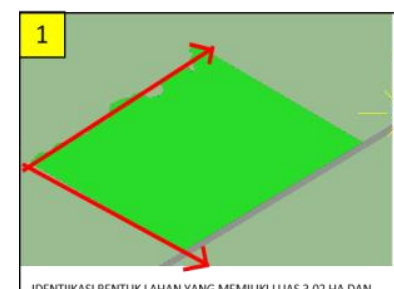

IDENTIIKASI BENTUK LAHAN YANG MEMLIKI LUAS 3,02 HA DAN
DAPAT DIAKSES DARI IL. KHATULSIWA DAN SUNGAI KAPUAS.

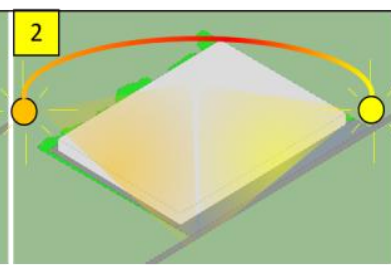

BANGUNAN DIEENTUK PERSEG DENGAN MEMAKSIMALKAN
IAHAN YANG TERSEDIA DAN MENGIDNTIEIKASI ARAH TIMUR

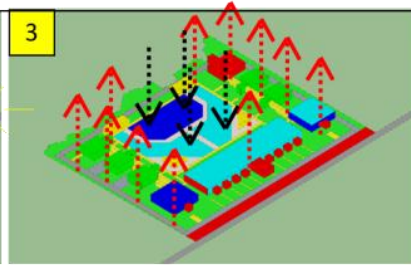

BANGUNAN DIBAGI MENAAD 9 BERDASARKAN ZONA DAN
FUNGSI.

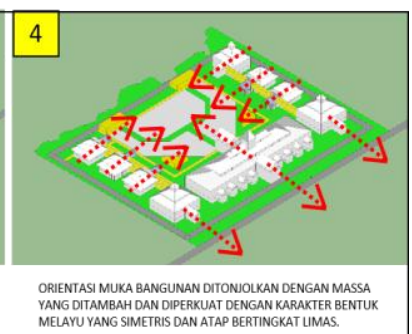

YANG DITAMBAH DAN DIPERKUAT DENGAN KARAKTER BENTU
MELAYYYANG SIMETRIS DAN ATAP BERTINGKAT UIMAS.

Gambar 8. Gubahan Bentuk Padepokan Seni dan Budaya Melayu Kalimantan Barat Sumber: Penulis, 2020

Analisis arsitektur lingkungan pada perancangan Padepokan Seni dan Budaya Melayu dapat dilihat pada gambar 9. Untuk mendukung pencahayaan alami bangunan, diterapkan skylight vertikal dari atas bangunan. Penghawaan alami didukung dengan penempatan kolam, penggunaan dinding trapezium, dan penggunaan kaca yang dapat menerap panas. Area plaza dimafaatkan sebagai ruang penyimpanan dan resapan air. Untuk mereduksi suara, kecepatan angin, dan termal pada bangunan, digunakan tanaman yang diletakkan pada sekeliling bangunan.

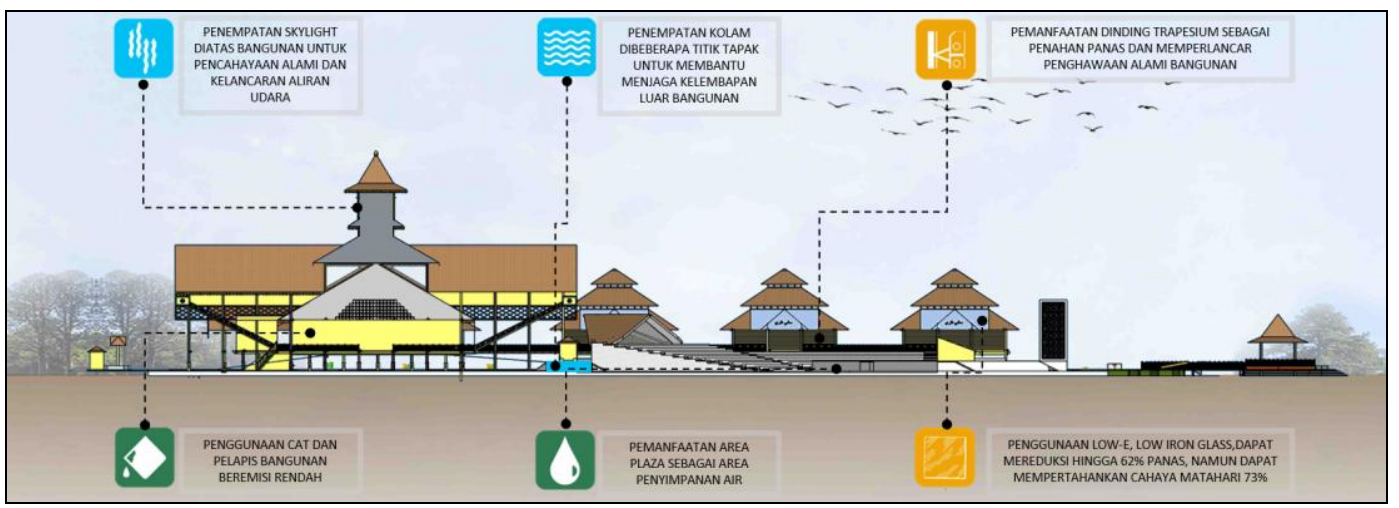

Gambar 9. Analisis Arsitektur Lingkungan Padepokan Seni dan Budaya Melayu Kalimantan Barat Sumber: Penulis, 2020

Analisis utilitas pada perancangan ini mencakup analisis kelistrikan, air bersih, sanitasi, tata udara, sistem kebakaran, persampahan, pengamanan bangunan, informasi dan komunikasi. Sumber listrik primer berasal dari Perusahaan Listrik Negara (PLN) dengan sumber sekundernya berasal generator set yang sesuai dengan kebutuhan. Untuk Sistem air bersih menggunakan up feed system dan down feed system. Tujuan dari penggunaan dua sistem yang berbeda yaitu untuk mengatasi kekurangan air pada saat musim kemarau dan dapat mengakomodasi kebutuhan air untuk penghuni (atlet) di dalam fungsi hunian khusus. Sistem sanitasi air limbah dialirkan dan ditampung ke dalam 
Septic Tank dan Bak Pemisah Lemak. Limbah. Air limbah kemudian dikumpulkan ke dalam Bak Kontrol, lalu di proses melalui Sumur Resapan lalu dialirkan melalui Riol Kota.

Sistem tata suara pusat data dihubungkan ke Public Announcement System (PAS) seperti mic paging dan equalizer. Dari PAS mengarah ke masing-masing unit speaker dan alarm kebakaran. Sistem penghawaan buatan, perancangan menggunakan Ceiling Fan yang disusun di ruangan yang terbuka. Pemilihan sistem Ceiling Fan bertujuan untuk mengurangi konsumsi energi untuk penghawaan gedung pada umumnya.

Sistem pengamanan bangunan terdiri dari pengamanan terhadap kebakaran dan keamanan bangunan. Pengamanan terhadap kebakaran secara aktif menggunakan hydrant dan APAR pada setiap area tertentu di bangunan dan kawasan. Kemanan bangunan didukung dengan sistem kontrol akses fisik, Closed Circuit Television (CCTV), komunikasi dan intercom, serta sistem deteksi.

Analisis struktur pada perancangan Padepokan Seni dan Budaya Melayu dapat dilihat pada gambar 10. Struktur bangunan Padepokan Seni dan Budaya Melayu Kalimantan Barat yang terdapat dalam Gambar 9 terbagi menjadi 3 yaitu, struktur bagian bawah (sub-structure), struktur bagian tengah (main-structure), dan struktur bagian atas (upper-structure). Konsep struktur Rumah Melayu juga meliputi struktur bangunan panggung, susunan grid, dan atap limasan. Lantai bangunan ditutup menggunakan Melamine Laminated Flooring untuk menciptakan nuansa Melayu kegiatan. Sistem portal bangunan panggung digunakan pada lantai dasar dan satu untuk mencegah penurunan tanah pada lantai dasar kerena kendaraan parkir. Dinding bangunan disusun diagonal dengan tulangan yang disabmbungkan dengan balok atas dan bawah.

Rangka atap berada pada bentangan $25 \mathrm{~m}$ untuk menghindari keberadaan kolom pada tengah ruangan. Rangka atap limas ditumpuk sebanyak tiga tingkat diperkuat dengan struktur rangka baja dengan posisi kuda-kuda yang melitang sepanjang bangunan. Struktur rangka baja yang terhubung hingga keatas meneruskan beban pasif dari rangka atap ke pondasi. Penutup atap bangunan menggunakan penutup genteng metal yang memiliki ketahanan yang tinggi. Secondary skin berwujud ukiran khas Melayu dirancang dengan bahan Aluminium Composite Panel (ACP).

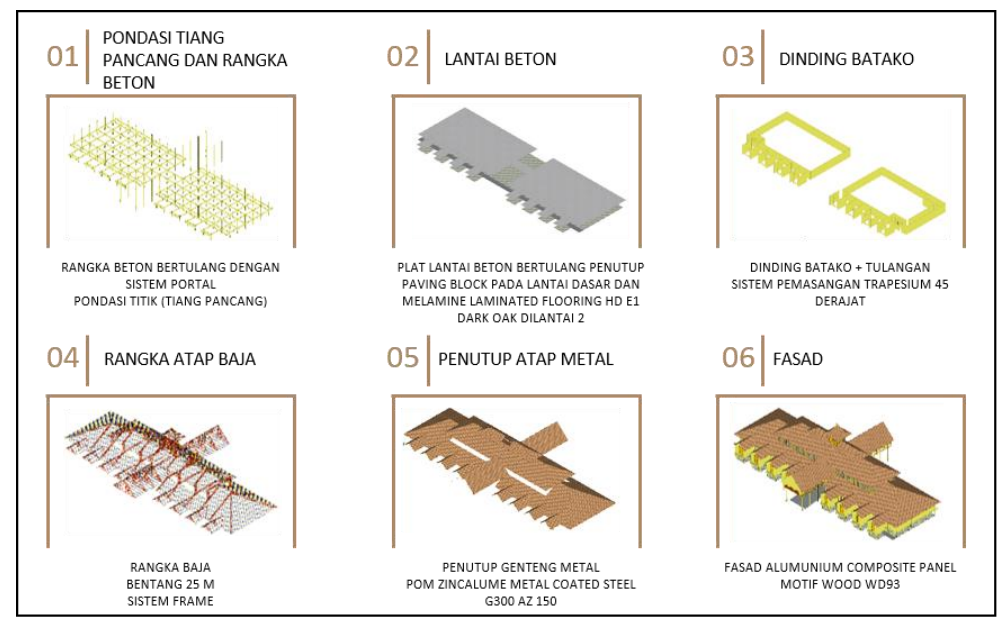

Gambar 10. Analisis Struktur Padepokan Seni dan Budaya Melayu Kalimantan Barat Sumber: Penulis, 2020

Keseluruhan analisis perancangan menghasilkan gambar siteplan Padepokan Seni dan Budaya Melayu Kalimantan Barat. Berdasarkan gambar siteplan, Luas lokasi perancangan berkisar 3,02 Ha. Lokasi perancangan dapat ditempuh dalam waktu 5 menit dari komplek Makam Kesultanan Batu Layang dan Tugu Khatulistiwa. Berdasarkan RTRW Kota Pontianak Tahun 2013-2033 Paragraf 4 pasal 20 poin c dan d, Komplek Makam Kesultanan Batu Layang dan Tugu Khatulistiwa termasuk dalam bangunan cagar budaya. Penentuan lokasi perancangan dipilih karena memiliki kaitan historis dalam permukiman Melayu dan identitas Kota Pontianak. 
Berdasarkan hasil analisis dan konsep keseluruhan, perancangan ini memperoleh hasil gambar pra-rancangan kawasan ruang luar/site plan. Rancangan meliputi bangunan utama dan area kawasan berupa area parkir murid, pengelola, dan pengunjung, area ruang terbuka publik, ruang terbuka semi privat.

Site plan Padepokan Seni dan Budaya Melayu Kalimantan Barat mempunyai sembilan bangunan utama yaitu bangunan utama (pameran dan pertunjukkan), masjid, bangunan pengelola, sanggar seni tari, sanggar seni musik, sanggar seni teater, sanggar seni kriya, sanggar seni memasak, dan rumah makan Melayu. Akses pada kawasan terbagi menjadi 2 jenis berdasarkan kendaraan maupun pejalan kaki, yaitu akses publik dan privat. Akses publik berfokus pada area depan bangunan utama, pengelola, dan masjid sesuai dengan zonasi tapak. Akses ini berperan sebagai jalur kendaraan sepeda, motor, mobil dan bus dan memiliki peruntukan kepada tamu dan pelaku utama kawasan seperti murid dan staf. Akses privat berfokus hanya pada pelaku utama seperti murid, pengajar/seniman, dan staf utama lainnya. Akses kendaraan privat ini berada pada zona terluar dari tapak agar pada area dalam tapak berfokus pada akses pejalan kaki. Area publik memiliki zona parkir yaitu sebanyak 126 buah motor dan 112 mobil untuk tamu serta 4 parkir bus. Area parkir privat yang tersedia untuk parkir pelaku utama berjumlah 224 motor untuk mahasiswa, 138 mobil untuk murid, 30 motor untuk staf pengajar/seniman, 56 mobil untuk staf pengelola termasuk staf servis dan administrasi. Gambar Siteplan disajikan pada Gambar 11.

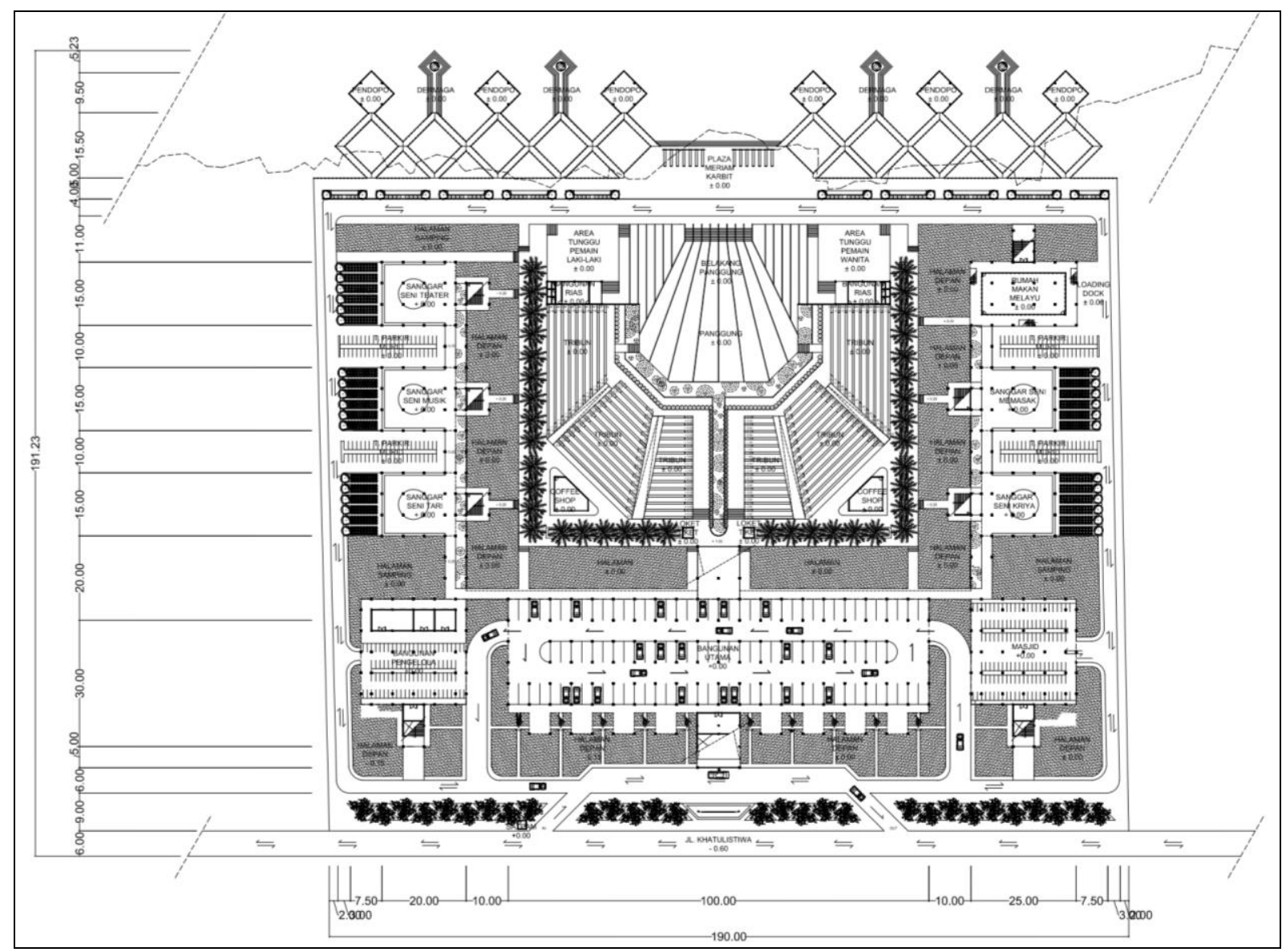

Gambar 11. Siteplan Padepokan Seni dan Budaya Melayu Kalimantan Barat

Sumber: Penulis, 2020

Denah lantai dasar gedung pameran dan pertunjukkan dapat dilihat pada Gambar 12. Gedung pameran dan pertunjukkan dibuat panggung dengan tinggi 3 meter agar terlihat lebih megah dari bangunan yang disekitarnya. Kolong dimanfaatkan sebagai area parkir mobil untuk memudahkan 
pelaku yang berteduh jika terkena hujan. Tangga sebanyak 10 buah diletakkan disepanjang bangunan depan untuk memudahkan pengunjung dalam mengakses bangunan. Perletakan tangga berada diantara stan untuk menarik perhatian pengunjung jika ingin membeli oleh-oleh.

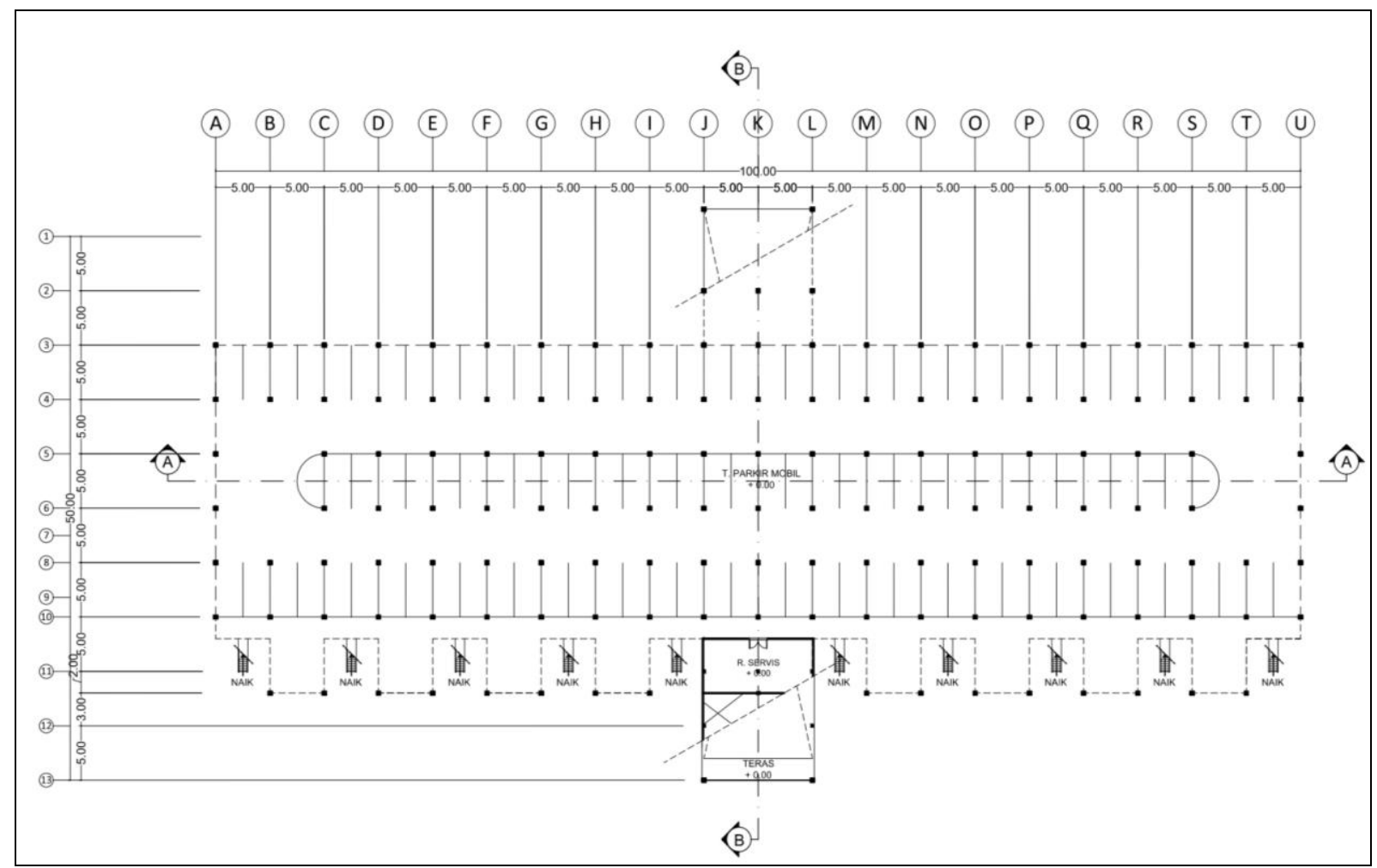

Gambar 12. Denah Lantai Dasar Padepokan Seni dan Budaya Melayu Kalimantan Barat

Sumber: Penulis, 2020

Denah lantai 1 gedung pameran dan pertunjukkan dapat dilihat pada Gambar 13. Gedung difungsikan sebagai stan, ruang galeri dan pertemuan. Area bagian depan diletakkan stan untuk pelaku yang berjualan oleh-oleh dikawasan. Stan dapat diakses langsung dari galeri dan ruang pertemuan. Stan juga dapat diakses melalui tangga dari area parkir mobil. Pada ruang bagian tengah digunakan untuk hall sebagai ruang awal masuk ke kawasan. Hall digabungkan dengan fungsi pusat informasi dan kemananan. Hall dapat diakses melalui ramp dari lantai dasar. Lantai 2 dapat diakses bangunan lain melalui selasar dari belakang bangunan. 


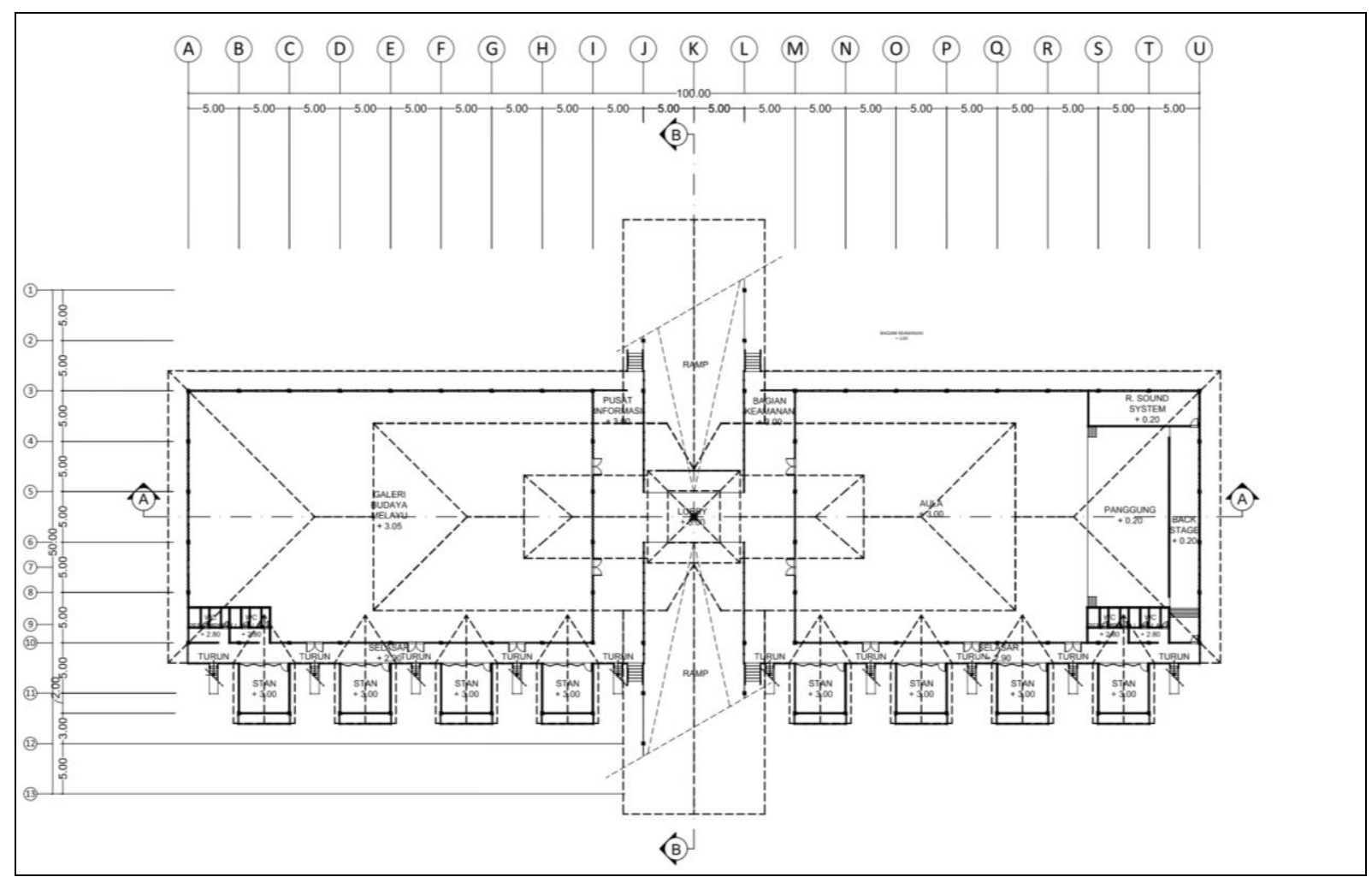

Gambar 13. Denah Lantai Satu Padepokan Seni dan Budaya Melayu Kalimantan Barat Sumber: Penulis, 2020

Bagian tampak depan bangunan dapat dilihat pada Gambar 14. Gambar tampak depan kawasan Padepokan Seni dan Budaya Melayu merupakan bentuk respon kawasan dengan orientasi tepat menghadap ke akses masuk kawasan. Hasil desain pada tampak depan ini menghadirkan plang nama dan akses masuk utama. Pada awal memasuki kawasan, pelaku perancangan akan memperoleh view dari 3 massa utama (gedung pengelola, pameran pertunjukkan, masjid) dan halaman luas untuk aktivitas taman dan parkir.

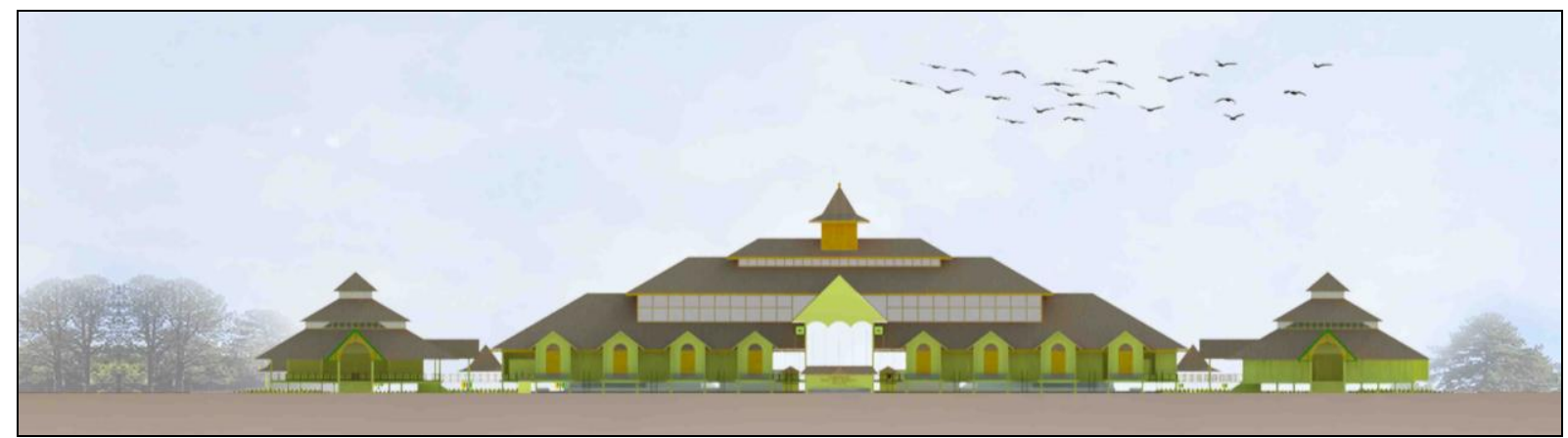

Gambar 14. Tampak Depan Padepokan Seni dan Budaya Melayu Kalimantan Barat Sumber: Penulis, 2020

Bagian kanan bangunan dapat dilihat pada Gambar 15. Tampak kanan kawasan menunjukkan jenis massa bangunan sebanyak 4 buah gedung utama yaitu gedung pameran pertunjukkan, sanggar seni musik, sanggar seni tari, sanggar seni teater. Gedung-gedung dikawasan terhubung dengan sebuah jembatan pada lantai kedua. Tampilan gedung memiliki kesamaan jenis bukaan yaitu dengan adanya permainan bukaan yang sama dan dipola berulang. Perbedaan tampilan bukaan bangunan yaitu pada jenis pintu, jendela, dan ventilasi bangunan. 


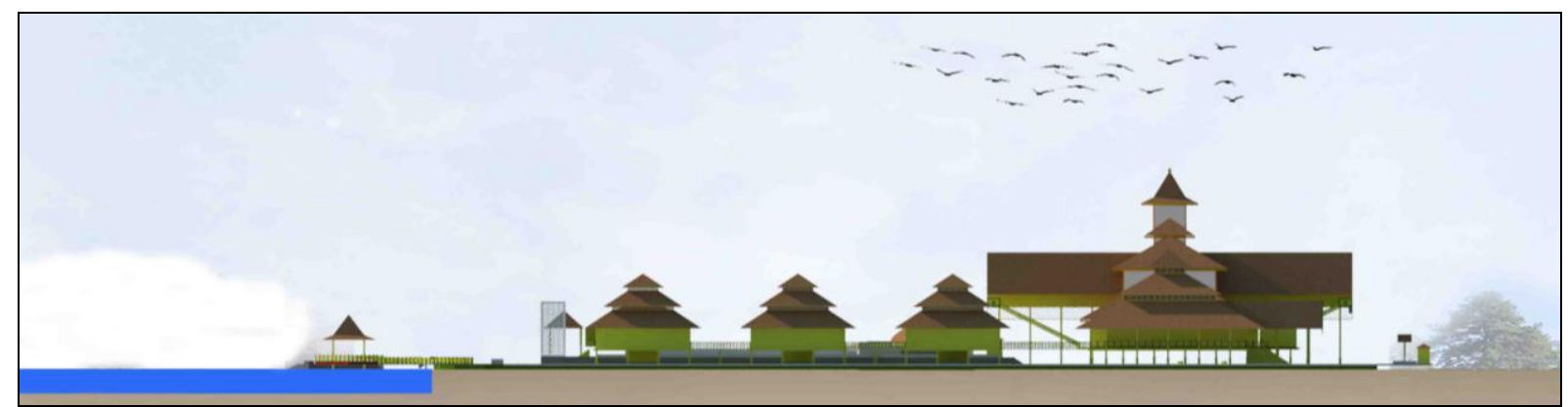

Gambar 15. Tampak Kanan Padepokan Seni dan Budaya Melayu Kalimantan Barat Sumber: Penulis, 2020

Bagian belakang bangunan dapat dilihat pada Gambar 16. Tampak belakang menampilkan massa gedung pameran pertunjukkan, sanggar seni teater, rumah makan dan pendopo. Fasad dari bangunan mengulang pola bukaan yang sama dengan pola kotak. Penggunaan atap didominasi dengan pelana sebagai entrance bangunan. Entrance rumah makan menggunakan atap limas. Ruang antar bangunan digunakan sebagai ruang terbuka berupa panggung, amphitheater dan plaza meriam karbit. Sebagai latar belakang panggung, digunakan pola vertikal berupa bidang-bidang yang terlihat berbeda dari berbagai sudut pandang.

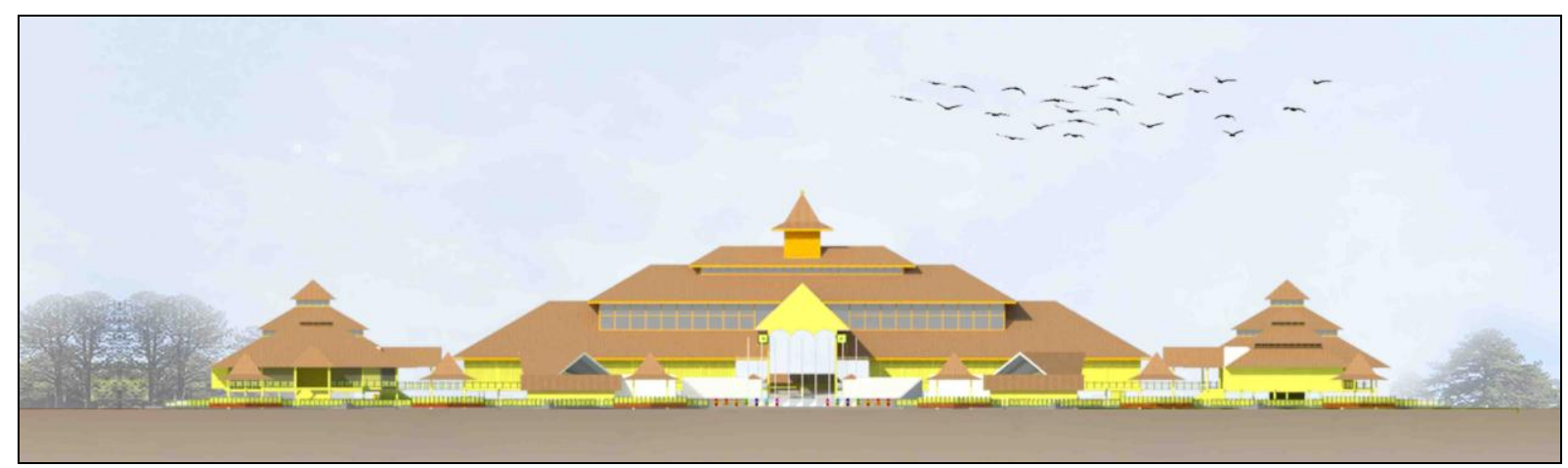

Gambar 16. Tampak Belakang Padepokan Seni dan Budaya Melayu Kalimantan Barat Sumber: Penulis, 2020

Bagian kiri bangunan dapat dilihat pada Gambar 17. Tampak kiri kawasan menampakkan 4 massa utama, yaitu gedung utama yaitu gedung pameran pertunjukkan, sanggar seni kriya, sanggar seni memasak dan rumah makan Melayu yang saling terhubung. Fasad dari empat gedung memiliki kesamaan dalam bukaan berupa jendela, pintu, dan ventilasi. Pola ini diulang secara konsisten dan teratur.

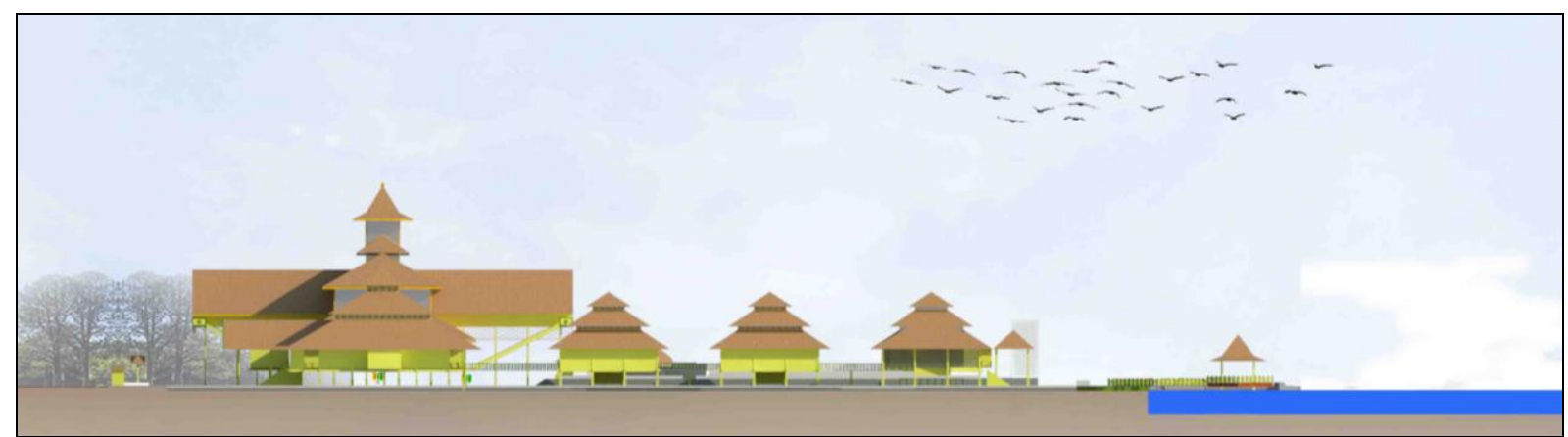

Gambar 17. Tampak Kiri Padepokan Seni dan Budaya Melayu Kalimantan Barat

Sumber: Penulis, 2020 
Gambar potongan memperlihatkan struktur atap bangunan yang membentang sepanjang 100 meter dengan tinggi dari lantai tempat parkir kendaraan, yaitu 5 meter. Struktur rangka ruang atap menumpu pada kolom yang menerus hingga ke pondasi. Bukaan di atas bangunan dirancang dengan kaca dengan tujuan memaksimalkan penerangan alami. Gambar potongan bangunan disajikan pada Gambar 18.

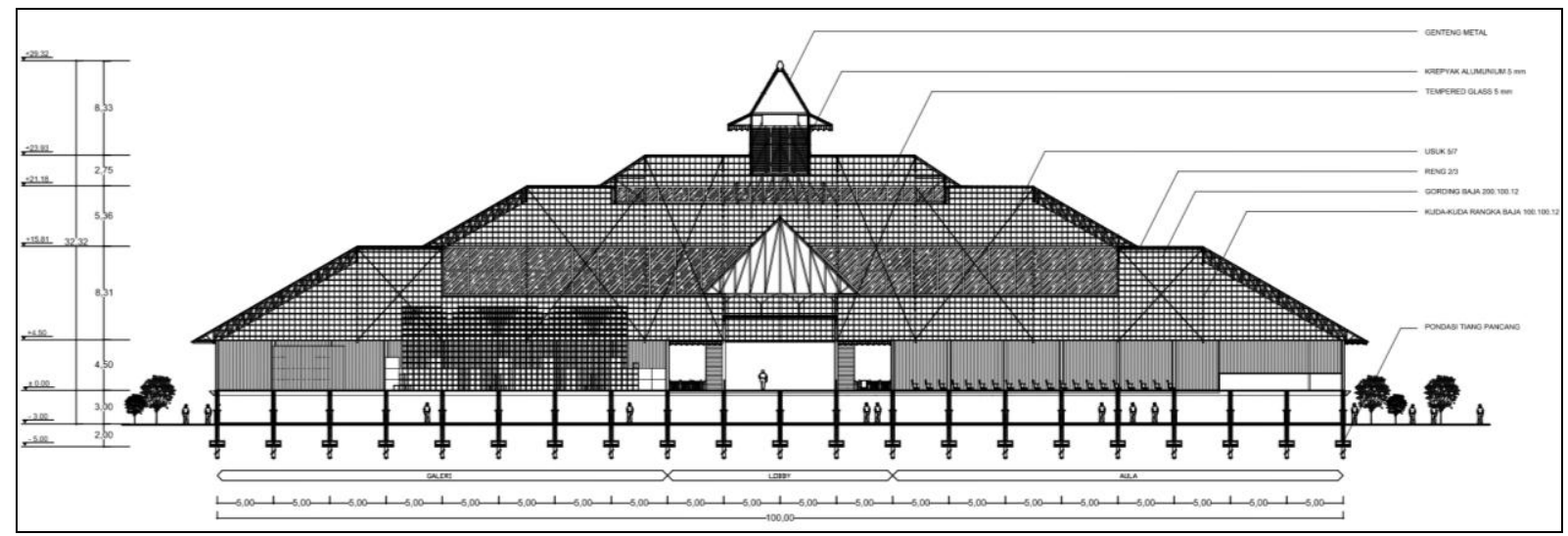

Gambar 18. Potongan A-A Gedung Utama Padepokan Seni dan Budaya Melayu Kalimantan Barat Sumber: Penulis, 2020

Suasana kawasan Padepokan Seni dan Budaya Melayu Kalimantan Barat dapat dilihat pada Gambar 19. Suasana menggambarkan letak bangunan yang berada tepat di tengah kawasan, dikelilingi oleh lanskap taman dan parkir. Letak sirkulasi publik berada di depan bangunan menghadap dengan akses utama, sedangkan letak sirkulasi privat berada di belakang bangunan. Pola sirkulasi yang terdapat dalam konsep perancangan berupa pola pencapaian melingkar guna mempermudah pengguna untuk masuk dan keluar dari kawasan.

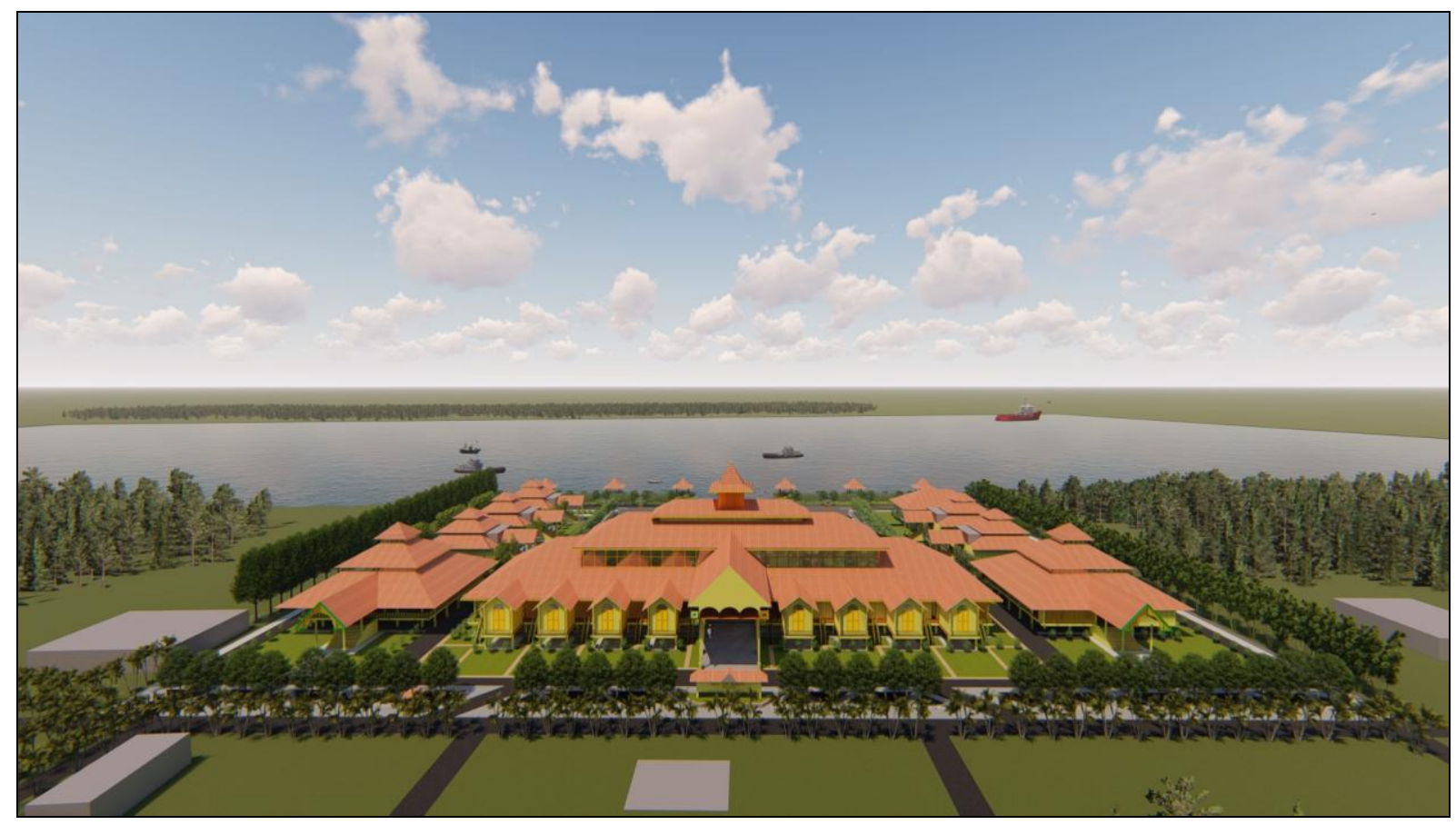

Gambar 19. Suasana Kawasan Padepokan Seni dan Budaya Melayu Kalimantan Barat Sumber: Penulis, 2020 
Suasana kawasan Padepokan Seni dan Budaya Melayu Kalimantan Barat dapat dilihat pada Gambar 20. Eksterior kawasan menekankan pada pengulangan bentuk pada bangunan untuk mengkoneksikan landscape dan bangunan. Permainan bentuk yang diulang menggambarkan konsistensi dan kedisiplinan seorang murid dalam menuntut ilmu. Fungsi tepian sungai dimanfaatkan sebagai plaza meriam karbit, pendopo, dan dermaga untuk mengkoneksikan site menuju jalur sungai. Panggung sebagai area pementasan terbuka dapat difungsikan sebagai plaza untuk mengadakan kegiatan budaya seperti robo-robo, seprahan, dan acara keagamaan. Amphiteater dipisahkan antara laki-laki dan perempuan untuk menjaga kehormatan pelaku sesuai aturan Islam.

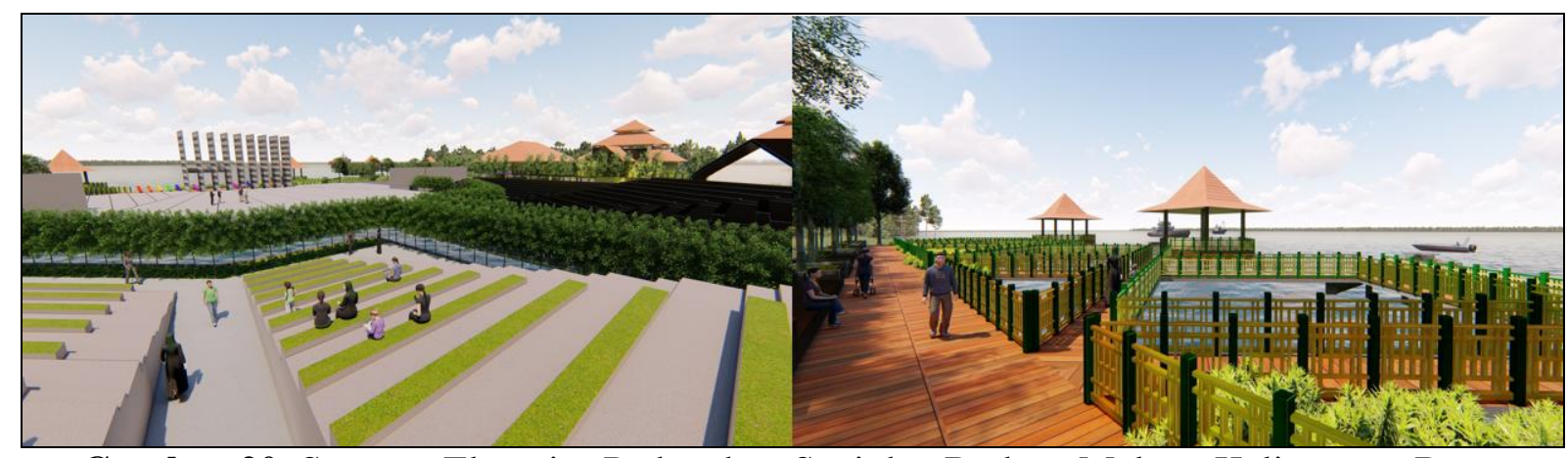

Gambar 20. Suasana Eksterior Padepokan Seni dan Budaya Melayu Kalimantan Barat Sumber: Penulis, 2020

Suasana interior dapat dilihat pada Gambar 21. Suasana interior menunjukkan gambar visualisasi kawasan Padepokan Seni dan Budaya Melayu Kalimantan Barat seperti detail hasil perancangan ruang dalam. Interior memperlihatkan suasana ruang-ruang tertentu di Padepokan Seni dan Budaya Melayu Kalimantan Barat. Interior tersebut memperlihatkan pemilihan material dan warna, perabot, dinding dan struktur bangunan agar pengunjung dapat menikmati suasana ruang yang interaktif dari segi pendidikan hingga terkait segi komersial. Interior bangunan merepresentasikan Arsitektur Melayu. Elemen kayu ditampilkan sebagai bentuk historis penggunaan kayu pada rumah melayu. Penggunaan dinding trapesium secara vertikal digunakan untuk menjaga privasi dari luar namun memungkinkan udara dapat masuk kedalam ruangan. Kotak-kotak kayu disusun secara linier dan berkelok untuk memberikan pengalaman yang unik bagi pengunjung galeri.

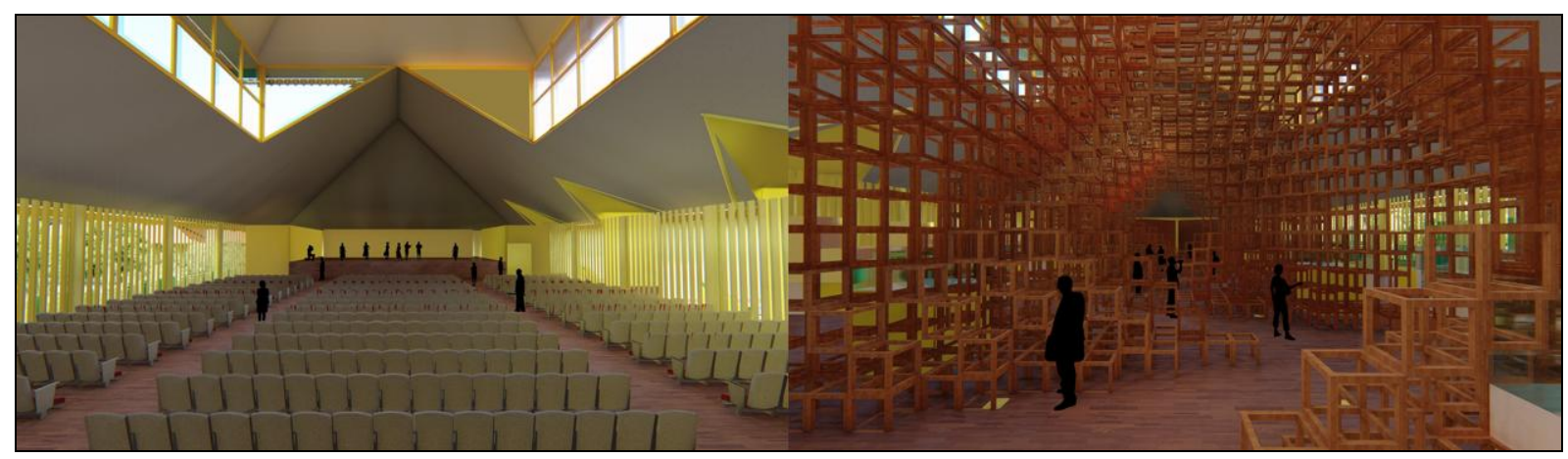

Gambar 21. Suasana Interior Padepokan Seni dan Budaya Melayu Kalimantan Barat Sumber: Penulis, 2020

\section{Kesimpulan}

Padepokan Seni dan Budaya Melayu Kalimantan Barat merupakan unit satuan pendidikan nonformal sejenis yang dilakukan oleh masyarakat untuk meningkatkan pengetahuan, keterampilan, dan sikap di wilayah Kalimantan Barat khususnya kesenian dan kebudayaan Melayu Kalimantan Barat. Untuk mengembangkan seniman-seniman baru dimasa depan, tersedia sarana gedung sanggar 
seni tari, musik, teater, kriya dan kuliner Melayu Kalimantan Barat. Disediakan juga fungsi pameran dan pertunjukkan yang dapat dilakukan secara indoor/outdoor untuk mengenalkan keanekaragaman budaya Melayu kepada pengunjung. Pengunjung juga dapat mengunjungi stan yang berada di area depan kawasan dan kuliner khas Melayu di gedung rumah makan Melayu di belakang kawasan sembari menikmati pemandangan Sungai Kapuas. Konsep perancangan Padepokan Seni dan Budaya Melayu Kalimantan Barat dimulai dari susunan ruang berdasarkan analisa zonasi bangunan Melayu yang disesuaikan dengan fungsi pendidikan padepokan. Kemudian fungsi dibuat mengelilingi fungsi plaza sebagai pusat dan ruang berkumpul. Ruang-ruang dibentuk secara grid secara eksternal dan internal untuk membentuk pola sirkulasi yang tegas dan jelas bagi pelaku. Karakteristik fasad merupakan hasil komposisi bangunan panggung berbentuk persegi yang dipadukan dengan atap limas yang ditumpuk 3 tingkat (islam, iman, ihsan). Atap bangunan dibuat limasan dengan sistem rangka frame. Kriteria dalam menentukan konsep secara arsitektural dan struktural yaitu berdasarkan konsep komposisi bentuk istana kesultanan Melayu di Kalimantan Barat dan di sesuaikan dengan fungsi dan lingkungan perancangan.

\section{Ucapan Terima Kasih}

Ucapan syukur kepada Tuhan Yang Maha Esa, kepada orang tua penulis, kepada para dosen pembimbing Proyek Tugas Akhir yaitu bapak Hamdil Khaliesh, S.T., M.T. selaku pembimbing utama dan bapak Irwin S.T., M.T. selaku pembimbing pendamping yang telah memberikan kritik dan saran untuk penulis. Kepada seluruh teman-teman dan keluarga yang telah banyak memberikan doa dan dukungan dalam pengerjaan Proyek Tugas Akhir ini, penulis mengucapkan rasa terima kasih yang sebesar-besarnya.

\section{Daftar Acuan}

Badan Perencanaan Pembangunan Daerah Kota Pontianak. (2013). Rencana Tata Ruang Wilayah (RTRW) Kota Pontianak Tahun 2013-2033. Pontianak: Badan Perencanaan Pembangunan Daerah Kota Pontianak

Elhullaimy, B. (1963). Asas Falsafah Kebangsaan Melayu. Jakarta: Tekad

Jones, J. (1980). Design Methods: Seeds of Human Future. New York: John Wiley \& Sons

Kementerian Pendidikan Dan Kebudayaan Republik Indonesia. (2017). Direktorat Pembinaan Kursus Dan Pelatihan Ditjen Pendidikan Anak Usia Dini Dan Pendidikan No. 16 Tahun 2017 Tentang Standar Sarana Dan Prasarana Lembaga Kursus Dan Pelatihan Masyarakat. Jakarta: Kementerian Pendidikan Dan Kebudayaan Republik Indonesia

Koentjaraningrat., 1993. Kebudayaan, Mentalitas, dan Pembangunan. Jakarta: Gramedia Pustaka Utama

Pemerintah Kota Pontianak. (2013). Peraturan Daerah Kota Pontianak No. 2 Tahun 2013 Tentang Rencana Tata Ruang Wilayah Kota Pontianak Tahun 2013-2033. Pontianak: Pemerintah Kota Pontianak

Soedarso, S.P. (1988). Tinjauan Seni, Sebuah Pengantar untuk Apresiasi Seni. Saku Dayar Sana. Yogyakarta

Tim Penyusun Kamus Besar Bahasa Indonesia. (2019, Nov 21). Arti Kata Padepokan. Retrieved from https://kbbi.web.id/pedepokan 